\title{
Restaurantes Self-Service no Município de Canoinhas (Sc): Segurança e Qualidade Microbiológica Dos Alimentos Servidos.
}

Daiana Alves Machado (I), Bruno Guilherme dos Santos (I), Jaqueline Costa Serafim Antunes (I), Graciele Viccini Isaka (I)

(I) IFSC - Instituto Federal de Santa Catarina - IFSC Campus Canoinhas (Av. Expedicionários, 2150, Campo da Água Verde, Canoinhas, SC)

\section{Resumo}

Os serviços de alimentação coletiva têm expandido em todo o mundo, com destaque para os restaurantes tipo self-service. Eles têm se destacando na epidemiologia dos surtos de doenças transmitidas por alimentos (DTAs). Diversos estudos revelam a baixa qualidade da matéria-prima, higienização dos utensílios utilizados, higiene dos manipuladores e monitoramento de parâmetros, como tempo e temperatura. O objetivo desta pesquisa foi avaliar a qualidade microbiológica de alimentos em 10 restaurantes tipo self-service em Canoinhas, por meio da aplicação de um questionário para avaliar o perfil socioeconômico e o nível de percepção de adoção de boas práticas de fabricação dos manipuladores de alimentos e dos proprietários, e da avaliação da temperatura de serviço e da qualidade microbiológica de dois alimentos da cadeia quente (macarrão e carne) e dois da cadeia fria (maionese e alface), em cada estabelecimento. Os resultados foram comparados com a Resolução RDC n ${ }^{\circ} 12$, de 2001, da ANVISA, e artigos científicos. Com base nos questionários, observou-se que $85,7 \%$ dos restaurantes possuem conhecimento sobre BPFs e microbiologia. A temperatura de $85,7 \%$ dos alimentos da cadeia quente e de $100 \%$ da cadeia fria estavam acima das temperaturas ideais. Nas análises de Salmonella spp. 57,2\% das amostras de carnes, 42,8\% das de macarrão, 100\% das de alface e de maionese, estavam acima do padrão estabelecido pela legislação. Para coliformes totais, $28,6 \%$ das amostras de carnes, $14,3 \%$ das 
de macarrão, $85,7 \%$ das de alface e $100 \%$ das de maionese também estavam fora do padrão. Para coliformes termotolerantes, 28,6\% das amostras de carnes, $57,2 \%$ das de alface e maionese estavam acima do permitido. As amostras de macarrão estavam de acordo com o padrão. Para bactérias aeróbias mesófilas, 28,6\% das amostras de alface e 14,3\% das de maionese estavam acima do permitido. Nas carnes e no macarrão, $100 \%$ das amostras estavam de acordo com o padrão. Para Bacillus cereus, 14,3\% das amostras de carne e de macarrão e 28,6\% das de maionese estavam fora do padrão. Para Estafilococus coagulase positiva, 28,6\% das amostras de macarrão e $71,4 \%$ das de maionese estavam fora do padrão. As amostras de carne estavam de acordo com a legislação. Assim, pode-se concluir que a maioria dos alimentos analisados estavam inadequados para o consumo humano para pelo menos um parâmetro microbiológico.

Palavras-Chave: Alimentação coletiva, Doença transmitida por alimento, Segurança alimentar

Agência de Fomento: IFSC 